Artikel Penelitian

\title{
Hubungan Kualitas Tidur dengan Tekanan Darah pada Pelajar Kelas 2 SMA Negeri 10 Padang
}

\author{
Mohd Luthfi B ${ }^{1}$, Syaiful Azmi ${ }^{2}$, Erkadius ${ }^{3}$
}

\begin{abstract}
Abstrak
Hipertensi didefinisikan dengan tekanan darah sistolik $\geq 140 \mathrm{mmHg}$ dan tekanan darah diastolik $\geq 90 \mathrm{mmHg}$. Hipertensi tidak hanya menyerang di usia tua saja, tetapi remaja juga bisa mengalaminya. Aktivitas yang padat pada remaja dan dewasa muda mengakibatkan mereka cenderung mengalami gangguan tidur yang merupakan salah faktor resiko terjadinya kenaikan tekanan darah. Tujuan penelitian ini adalah untuk menentukan hubungan antara kualitas tidur dan tekanan darah pada pelajar kelas 2 SMA Negeri 10 Padang. Metode yang digunakan adalah analitik deskriptif dengan sampel adalah 153 orang siswa kelas 2 SMA Negeri 10 Padang yang termasuk kriteria inklusi dan eklusi. Penilaian kualitas tidur dengan menggunakan kuesioner Pittsburgh Sleep Quality Index (PSQI) dan tekanan darah dengan menggunakan sphygmomanometer air raksa dan stetoskop. Data dianalisis menggunakan uji statistik " $t$ independent". Hasil penelitian menunjukkan kualitas tidur buruk sebanyak 106 orang (69,3\%) dan baik sebanyak 47 orang (30,7\%). Rata-rata tekanan darah sistolik dan diastolik subjek adalah 114,28 mmHg dan 73,13 mmHg. Hasil analisis data statistik kualitas tidur dengan tekanan darah sistolik didapatkan $p=0,000$ dan diastolik didapatkan $p=0,000$. Simpulan studi ialah terdapat perbedaan yang bermakna $(p<0,05)$.
\end{abstract}

Kata kunci: kualitas tidur, tekanan darah, PSQI

\begin{abstract}
Hypertension is defined by systolic blood pressure $\geq 140 \mathrm{mmHg}$ and diastolic blood pressure $\geq 90 \mathrm{mmHg}$. Hypertension is not only attacking in old age, but teens can also experience it. Solid activity in adolescents and young adults result they tend to experience sleep disturbances, which is one risk factor for the increase in blood pressure. The objective of this study was to determine relationship between the sleep quality and blood pressure in grade 2 student SMA Negeri 10 Padang. This research was conducted in SMA Negeri 10 Padang. The method used was a descriptive analytic sample was 153 students of class 2 SMA Negeri 10 Padang including inclusion and exclusion criteria. Sleep quality assessment using questionnaires Pittsburgh Sleep Quality Index (PSQI), and blood pressure using a sphygmomanometer and stethoscope. Data were analyzed using the statistical test "T-independent". The results showed poor sleep quality were 106 persons (69.3\%) and a good many as 47 people (30.7\%). Average systolic and diastolic blood pressure of subjects was $114.28 \mathrm{mmHg}$ and $73.13 \mathrm{mmHg}$. From the analysis of statistical data quality sleep systolic blood pressure obtained $p=0.000$ and diastolic $p=0.000$. The conclusion is a significant difference $(p<0.05)$.
\end{abstract}

Keywords: sleep quality, blood pressure, PSQI

Affiliasi penulis: 1. Prodi Profesi Dokter FK Unand (Fakultas Kedokteran Universitas Andalas Padang), 2. Bagian Penyakit Dalam FK Unand/RSUP Dr. M.Djamil Padang, 3. Bagian Fisiologi FK Unand. Korespondensi: Mohd Luthfi B, Email: m.luthfixs@gmail.com, Telp: +6282389230318

\section{PENDAHULUAN}

Hipertensi dan komplikasinya adalah salah satu penyebab kematian nomor satu secara global. Hipertensi didefinisikan dengan tekanan darah sistolik $\geq 140 \mathrm{mmHg}$ dan tekanan darah diastolik $\geq 90 \mathrm{mmHg}$ 
menurut JNC VII. Komplikasi pembuluh darah yang disebabkan hipertensi dapat menyebabkan penyakit jantung koroner, infark (kerusakan jaringan) jantung, stroke dan gagal ginjal. Komplikasi pada organ tubuh dapat menyebabkan angka kematian yang tinggi. Penyakit kardiovaskuler menduduki angka kematian nomor satu di Indonesia dan sebanyak 20-35\% kematian disebabkan hipertensi. ${ }^{1,2}$

Hipertensi tidak hanya menyerang di usia tua saja, tetapi remaja juga bisa mengalaminya. Hal ini terbukti antara tahun 1988 dan 1999, prehipertensi dan hipertensi diperkirakan meningkat secara nyata pada anak-anak dan remaja sebesar $2,3 \%$ dan $1 \% .^{3}$

Prevalensi hipertensi remaja di seluruh dunia sekitar $15-20 \%$ populasi. Berdasarkan data hasil pencatatan dan pelaporan Riskesdas Depkes RI tahun 2007 prevalensi hipertensi remaja sekitar 6$15 \%$. Prevalensi hipertensi pada usia muda di Kota Semarang terjadi sebanyak 164 kasus (6,01\%). Dari 164 kasus tersebut, sebanyak $6-10 \%$ sudah mengalami komplikasi seperti penyakit jantung, ginjal, dan lain-lain. ${ }^{2}$

Remaja adalah kelompok beresiko tinggi mengalami gangguan tidur. Prevalensi gangguan tidur pada remaja dari berbagai penelitian menunjukan hasil yang bervariasi. Liu et al mendapatkan $21,2 \%$ anak usia 2 sampai 12 tahun di Beijing mengalami gangguan tidur. Penelitian Ohida et al terhadap siswa SMP dan SMU menunjukkkan prevalensi gangguan tidur bervariasi mulai $15,3 \%$ hingga $39,2 \%$ bergantung pada jenis gangguan tidur yang dialami. ${ }^{4,5,6}$

Pada remaja terdapat perubahan dramatis dalam pola tidur-siaga selama remaja, termasuk berkurangnya durasi tidur, tertundanya waktu tidur, dan bertambahnya perbedaan pola tidur pada hari kerja dan akhir pekan. Kualitas tidur pada remaja juga cenderung berkurang. ${ }^{7}$

Dr. Sogol Javaheri et al dari Cave Western Reserve School of Medicine, Claveland, melakukan sebuah penelitian untuk mengetahui hubungan antara kualitas tidur yang buruk dengan prehipertensi atau hipertensi pada remaja, dan penelitian ini adalah penelitian pertama yang dilakukan dengan tujuan untuk mengetahui kedua hubungan tersebut. Penelitian ini dipublikasikan pada tanggal 18 Agustus
2008 dalam jurnal Circulation. $\mathrm{Dr}$ Javaheri mengatakan bahwa data mengenai hubungan peningkatan tekanan darah karena kualitas tidur yang buruk pada orang dewasa sudah banyak, tetapi pada remaja masih belum jelas. ${ }^{8}$

Berdasarkan latar belakang di atas maka perlu untuk mendapatkan data mengenai prevalensi hipertensi pada remaja di Indonesia, khususnya SMA N 10 Padang.

\section{METODE}

Rancangan penelitian yang digunakan adalah penelitian deskriptif analitik dengan desain crosssectional. Sampel penelitian ini adalah 153 orang siswa kelas 2 SMA Negeri 10 Padang yang termasuk kriteria inklusi dan eklusi. Penelitian ini dilakukan tanggal 1 dan 8 Maret 2014. Penilaian kualitas tidur dengan menggunakan kuesioner Pittsburgh Sleep Quality Index(PSQI) dan tekanan darah dengan menggunakan sphygmomanometer air raksa dan stetoskop.

HASIL

Tabel 1. Distribusi subyek menurut umur

\begin{tabular}{ccc}
\hline Umur & $\mathbf{n}$ & $\%$ \\
\hline 16 & 4 & 2.6 \\
17 & 110 & 71.9 \\
18 & 39 & 25.5 \\
\hline Total & 153 & 100 \\
\hline
\end{tabular}

Pada Tabel 1 didapatkan subyek penelitian terbanyak umur 17 tahun sebanyak 110 orang $(71,9 \%)$, diikuti umur 18 tahun sebanyak 39 orang $(25,5 \%)$ dan umur 16 tahun sebanyak 4 orang $(2,6 \%)$.

Tabel 2. Distribusi subyek menurut jenis kelamin

\begin{tabular}{ccc}
\hline Jenis Kelamin & $\mathbf{n}$ & $\%$ \\
\hline Laki-laki & 53 & 34.6 \\
Perempuan & 100 & 65.4 \\
\hline Total & 153 & 100 \\
\hline
\end{tabular}

Berdasarkan Tabel 2 didapatkan subyek penelitian terbanyak adalah perempuan berjumlah 100 orang $(65,4 \%)$ sedangkan laki-laki berjumlah 53 orang $(34,6 \%)$. 
Tabel 3. Distribusi subyek menurut kualitas tidur

\begin{tabular}{ccc}
\hline Kualitas Tidur & $\mathbf{n}$ & $\%$ \\
\hline Baik & 47 & 30.7 \\
Buruk & 106 & 69.3 \\
\hline Total & 153 & 100 \\
\hline
\end{tabular}

Pada Tabel 3 didapatkan golongan kualitas tidur terbanyak subyek penelitian adalah kualitas tidur buruk sebanyak 106 orang $(69,3 \%)$,diikuti kualitas tidur baik sebanyak 47 orang $(30,7 \%)$.

Tabel 4. Distribusi kualitas tidur baik menurut jenis kelamin

\begin{tabular}{ccc}
\hline Jenis Kelamin & $\mathbf{n}$ & $\%$ \\
\hline Laki-laki & 16 & 34.1 \\
Perempuan & 31 & 65.9 \\
\hline Total & 47 & 100 \\
\hline
\end{tabular}

Berdasarkan Tabel 4 didapatkan jenis kelamin dengan kualitas tidur baik terbanyak adalah perempuan sebanyak 31 orang $(65,9 \%)$, diikuti lakilaki sebanyak 16 orang $(34,1 \%)$.

Tabel 5. Distribusi kualitas tidur buruk menurut jenis kelamin

\begin{tabular}{ccc}
\hline Jenis Kelamin & $\mathbf{n}$ & \% \\
\hline Laki-laki & 37 & 34.9 \\
Perempuan & 69 & 65.1 \\
\hline Total & 106 & 100 \\
\hline
\end{tabular}

Pada Tabel 5 didapatkan jenis kelamin dengan kualitas tidur baik terbanyak adalah perempuan sebanyak 31 orang $(65,9 \%)$, diikuti laki-laki sebanyak 16 orang $(34,1 \%)$.

Tabel 6. Distribusi gambaran rata-rata tekanan darah sistolik dan disatolik

\begin{tabular}{ccc}
\hline Tekanan Darah & $\begin{array}{c}\text { rata-rata } \\
(\mathbf{m m H g})\end{array}$ & SD \\
\hline Sistolik & 114.28 & \pm 9.52 \\
Diastolik & 73.13 & \pm 7.64 \\
\hline
\end{tabular}

Berdasarkan Tabel 6 didapatkan rata-rata tekanan darah sistolik dan diastolik subjek adalah $114,28 \mathrm{mmHg}$ dan $73,13 \mathrm{mmHg}$.
Tabel 7. Distribusi gambaran tekanan darah sistolik

\begin{tabular}{ccc}
\hline $\begin{array}{c}\text { Tekanan Darah } \\
\text { Sistolik }\end{array}$ & $\mathbf{n}$ & $\%$ \\
\hline$<120 \mathrm{mmHg}$ & 81 & 52.9 \\
$120-139 \mathrm{mmHg}$ & 71 & 46.4 \\
$140-159 \mathrm{mmHg}$ & 1 & 0.7 \\
$\geq 160 \mathrm{mmHg}$ & 0 & 0 \\
\hline Total & 153 & 100 \\
\hline
\end{tabular}

Berdasarkan Tabel 7 didapatkan golongan terbanyak tekanan darah sistolik subyek penelitian adalah $<120 \mathrm{mmHg}$ yaitu sebanyak 81 orang $(52,9 \%)$, diikuti oleh $120-139 \mathrm{mmHg}$ sebanyak 71 orang $(46,4 \%)$ dan yang paling sedikit $140-19 \mathrm{mmHg}$ yaitu sebanyak 1 orang $(0,7 \%)$ dengan responden yang mengalami peningkatan tekanan darah sistolik (sistolik $\geq 120 \mathrm{mmHg}$ ) sebanyak 72 orang $(47,1 \%)$.

Tabel 8. Distribusi gambaran tekanan darah diastolik

\begin{tabular}{ccc}
\hline $\begin{array}{c}\text { Tekanan Darah } \\
\text { Diastolik }\end{array}$ & $\mathbf{n}$ & $\%$ \\
\hline$<80 \mathrm{mmHg}$ & 88 & 57.5 \\
$80-89 \mathrm{mmHg}$ & 62 & 40.5 \\
$90-99 \mathrm{mmHg}$ & 3 & 2 \\
$\geq 100$ & 0 & 0 \\
\hline Total & 153 & 100 \\
\hline
\end{tabular}

Berdasarkan Tabel 8 didapatkan golongan terbanyak tekanan darah diastolik subyek penelitian adalah $<80 \mathrm{mmHg}$ sebanyak 88 orang $(57,5 \%)$ diikuti oleh $80-89 \mathrm{mmHg}$ sebanyak 62 orang $(40,5 \%)$ dan yang paling sedikit yaitu $90-99 \mathrm{mmHg}$ sebanyak 3 orang $(2 \%)$ dengan responden yang mengalami peningkatan tekanan darah diastolik (diastolik $\geq 80$ $\mathrm{mmHg}$ ) sebanyak 65 orang (42.5\%).

Tabel 9. Pengelompokan rata-rata tekanan darah sistolik dan diastolik berdasarkan tekan kualitas tidur

\begin{tabular}{ccc}
\hline $\begin{array}{c}\text { Kualitas } \\
\text { Tidur }\end{array}$ & $\begin{array}{c}\text { Rata-rata } \\
\text { Tekanan darah } \\
\text { sistolik } \\
(\mathbf{m m H g})\end{array}$ & $\begin{array}{c}\text { Rata- rata } \\
\text { Tekanan darah } \\
\text { diastolik } \\
(\mathbf{m m H g})\end{array}$ \\
\hline Baik & $108.51 \pm 8.269$ & $68.93 \pm 7.656$ \\
Buruk & $116.83 \pm 8.926$ & $74.99 \pm 6.891$ \\
\hline
\end{tabular}


Hubungan kualitas tidur dengan tekanan darah sistolik maupun diastolik pada Tabel 9 menunjukkan bahwa rata-rata tekanan darah sistolik pada kualitas tidur baik adalah 108,51dan tekanan darah sistolik pada kualitas tidur buruk adalah 116,83. Tekanan darah diastolik didapatkan bahwa rata-rata tekanan darah diastolik pada kualitas tidur yang baik adalah 68,93 dan tekanan darah diastolik pada kualitas tidur yang buruk adalah 74,99 .

Tabel 10. Analisis hubungan antara kualitas tidur dengan tekanan darah sistolik dan diastolik

\begin{tabular}{|c|c|c|c|c|c|}
\hline & \multicolumn{5}{|c|}{$95 \% \mathrm{Cl}$} \\
\hline & Rerata & TINGGI & RENDAH & $\mathbf{P}$ & $\mathbf{n}$ \\
\hline SISTOLIK & & & & & \\
\hline Kualitas & 108.51 & & & & 47 \\
\hline tlour DalK & & 11.35 & 5.35 & .000 & \\
\hline $\begin{array}{l}\text { Kualitas } \\
\text { tidur buruk }\end{array}$ & 116.83 & & & & 106 \\
\hline DIASTOLIK & & & & & \\
\hline $\begin{array}{l}\text { Kualitas } \\
\text { tidur baik }\end{array}$ & 68.93 & & & & 47 \\
\hline $\begin{array}{l}\text { Kualitas } \\
\text { tidur buruk }\end{array}$ & 74.99 & 8.52 & 3.58 & .000 & 106 \\
\hline
\end{tabular}

Tabel 10 menunjukkan rerata perbedaan tekanan darah sistolik menurut kualitas tidur antara 5,35 sampai 11,35 (IK95\%). Dari hasil analisis statistik didapatkan bahwa hasil uji varian $(F)$ didapat $p=0,951$ $(p>0,05)$ yang berarti tidak terdapat perbedaan varian sehingga uji yang dilakukan adalah uji t dengan varian yang sama. Hasil uji $t=5,443$ dan $p=0,000$ Hal ini berarti terdapat hubungan yang bermakna rata-rata tekanan darah sistolik menurut kualitas tidur $(p<0,05)$.

rata-rata perbedaan tekanan darah diastolik menurut kualitas tidur antara 3.58 sampai 8.52 (IK95\%). Dari hasil analisis data statistik didapatkan bahwa hasil uji varian $(F)$ didapatkan $p=0,951$ yang berarti tidak terdapat perbedaan varian sehingga uji yang dilakukan adalah dengan uji $\mathrm{t}$ dengan varian yang sama. Hasil uji $t=5,4$ dan $p=0,000$. Hal ini berarti terdapat perbedaan yang bermakna rata-rata tekanan darah diastolik menurut kualitas tidur $(p<0,05)$.

\section{PEMBAHASAN}

Subjek pada penelitian ini memiliki rentang umur antara 16-18 tahun, dengan golongan terbanyak yaitu umur 17 tahun sebanyak 110 orang $(71,9 \%)$. Artinya rentang umur responden pada penelitian ini berbeda dengan penelitian Javaheri et al (2008) yang memiliki rentang umur 13-16 tahun.Dalam penelitian ini jenis kelamin sampel didominasi oleh perempuan yaitu sebanyak 100 orang $(65,4 \%)$, hal ini berbeda dengan penelitian Javaheri et al (2008) dimana terdapat $51,7 \%$ responden laki-laki. Hal ini dikarenakan jumlah pelajar kelas 2 SMA Negeri 10 Padang lebih banyak dengan jenis kelamin perempuan. $^{8}$

Penggolongan kualitas tidur pada penelitian ini yaitu berdasarkan skor dari kuesioner Pittsburg Sleep Quality Index (PSQI), dimana bila jumlah skor $>5$ artinya koresponden memiliki kualitas tidur yang buruk dan skor $<5$ berarti responden memiliki kualita tidur yang baik. Hasil penelitian mendapatkan bahwa jumlah responden yang memiliki kualitas tidur yang buruk sebanyak 106 orang $(69,3 \%)$ dan kualitas tidur yang baik sebanyak 47 orang $(30,7 \%)$. Bila dibandingkan dengan penelitian Javaheri et al (2008) pada 238 responden, yang meiliki kualitas tidur yang buruk sebanyak 61 orang $(25,6 \%)$ dan kualitas tidur baik sebanyak 177 orang (74,4\%). Artinya jumlah responden yang memiliki kualitas tidur yang buruk pada penelitian ini lebih banyak daripada penelitian Javaheri et al (2008).,

Faktor seperti akses internet, peralatan elektronik di kamar tidur seperti televisi dan jadwal sekolah yang padat, peningkatan konsumsi kafein dan faktor-faktor stres lainnya diduga menjadi penyebab penurunan kualitas tidur pada remaja. ${ }^{3}$

Hasil penelitian didapatkan rata-rata tekanan darah sistolik sebesar $114,28 \mathrm{mmHg}$ dan diastolik sebesar $73.13 \mathrm{mmHg}$. Artinya rata-rata tekanan darah sistolik dan diastolik pada penelitian ini lebih tinggi daripada penelitian Angkat (2009), dengan responden dengan umur 15-17 tahun yang memiliki rata-rata tekanan darah sistolik dan diastolik sebesar 110,25 $\mathrm{mmHg}$ dan $72,14 \mathrm{mmHg}{ }^{10}$

Jumlah responden yang mengalami peningkatan sistolik $(\geq 120 \mathrm{mmHg}$ ) yaitu sebanyak 21 orang $(13,72 \%)$ dan peningkatan diastolik $(\geq 80 \mathrm{mmHg}$ ) yaitu sebanyak 4 orang $(2,61 \%)$. Hal ini sesuai dengan penelitian Angkat (2009), dari keseluruhan responden berjumlah 287 orang didapatkan responden yang 
mengalami peningkatan sistolik sebanyak 28 orang $(9,8 \%)$ dan peningkatan diastolik sebanyak 20 orang $(7 \%){ }^{10}$

Seluruh subjek yang diambil di SMA Negeri 10 Padang didapatkan pelajar yang mengalami hipertensi atau sistolik di atas atau sama dengan $140 \mathrm{mmHg}$ sebanyak 1 orang $(0,7 \%)$ sedangkan yang mengalami peningkatan tekanan darah diastolik di atas atau sama dengan $90 \mathrm{mmHg}$ sebanyak 3 orang (2\%). Hal tersebut kurang lebih sama menurut suatu penelitian yakni dari 203 pelajar berumur 12-17 tahun, didapatkan 10 pelajar dengan tekanan darah sistolik sama atau lebih dari $140 \mathrm{mmHg}$ dan tekanan diastolik sama atau lebih dari $90 \mathrm{mmHg} .^{11}$

Faktor seperti genetik, BMI, aktivitas fisik, kebiasaan konsumsi makanan tinggi garam, merokok, alkohol diduga berhubungan dengan peningkatan tekanan darah sistolik dan diastolik pada remaja. ${ }^{12}$

Pada penelitian ini didapatkan bahwa terdapat perbedaan kualitas tidur yang baik maupun buruk dengan tekanan darah sistolik maupun diastolik $(p<0,05)$. Terdapat perbedaan rata-rata tekanan darah sistolik antara kualitas tidur baik dengan kualitas tidur buruk sebesar $8,32 \mathrm{mmHg}$, dimana tekanan sistolik dengan kualitas tidur buruk cenderung lebih tinggi. Ada terdapat perbedaan rata-rata tekanan darah diastolik antara kualitas tidur baik dengan kualitas tidur buruk sebesar 6,06 mmHg dimana kualitas tidur buruk cenderung lebih tinggi. Hal ini sesuai dengan penelitian Javaheri et al (2008), dimana remaja dengan kualitas tidur yang buruk mengalami peningkatan tekanan darah sistolik sebesar $4 \pm 1,2$ $\mathrm{mmHg}$ dan diastolik sebesar $1,7 \pm 1,2 \mathrm{mmHg}^{8}$

Peningkatan ini sesuai dengan kepustakaan yang menyatakan bahwa gangguan tidur yang terjadi secara terus-menerus dapat menyebabkan perubahan fisiologi tubuh dimana keseimbangan antara pengaturan sistem saraf simpatis dan parasimpatis terganggu. Simpatis akan ditingkatkan sehingga memicu terjadinya peningkatan tekanan darah pada orang yang mengalami gangguan tidur tersebut. Sebaliknya sistem parasimpatis diturunkan. ${ }^{13}$

Kualitas tidur yang buruk tidak hanya dikaitkan dengan gangguan tidur tetapi juga dengan durasi tidur. Durasi tidur yang lebih pendek akan meningkatkan beban hemodinamik 24 jam secara bertahap, meningkatkan aktivitas sistem saraf simpatis, lamanya paparan faktor stres fisik dan psikososial saat keadaan jaga dan meningkatkan nafsu garam serta meningkatkan retensi garam. Paparan yang lebih lama maka faktor diatas menyebabkan adaptasi struktural sistem kardiovaskular, seperti konstriksi arteri dan hipertrofi ventrikel kiri yang bisa meningkatkan keseimbangan tekanan darah secara bertahap. ${ }^{14}$

\section{SIMPULAN}

Terdapat hubungan antara kualitas tidur dengan tekanan darah pada pelajar kelas 2 di SMA Negeri 10 Padang.

\section{DAFTAR PUSTAKA}

1. JNC VII. The seventh report of the Joint National Committee on prevention, detection, evaluation, and treatment of high blood pressure. Hypertension. 2003;42:1206-52.

2. Departemen Kesehatan Republik Indonesia. InaSH menyokong penuh penanggulangan hipertensi. Pusat Komunikasi Publik: Sekretariat Jenderal Departemen Kesehatan; 2007.

3. Redwine KM, Daniels SR. Prehypertension in adolescents: risk and progression. The Journal of Clinical Hypertension. 2012;14(6):360-4.

4. National Sleep Foundation."Sleep in America" Poll. Washington, DC: National Sleep Foundation;2002.

5. Liu X, Yuyan M, Yizhuo W, Jiang Q, Rao X, Lu X, et al. Brief report: an epidemiologic survey of the prevalence of sleep disorders among children 2 to 12 years old in Beijing, China. Pediatrics. 2005;115:266-8.

6. Ohida $\mathrm{T}$, Osaki $\mathrm{Y}$, Doi $\mathrm{Y}$, Tanihata $\mathrm{T}$, Minowa $\mathrm{M}$, Suzuki $\mathrm{K}$, et al. An epidemiologic study of selfreported sleep problems among Japanese adolescents. Sleep. 2004;27:978-85.

7. LeBourgeois MK, Giannotti F, Cortesi F, Wolfson $A R$, Harsh J. The relationship between reported sleep quality and sleep hygiene in Italian and American adolescents. Pediatrics. 2005;115:25765.

8. Javaheri, et al. Sleep quality and elevate blood pressure in adolescent. AHA Inc. Journal Circulation.2008;118:1034-40. 
9. Buyse D, et al. The Pittsburgh sleep quality index:a new instrument for phsychiatric practice and reasearch. Phsychiatric Research. 1989;28(2):. 193-213.

10. Angkat DN. Hubungan kualitas tidur dengan tekanan darah pada remaja usia 15-17 tahun di SMA Negeri 1 Tanjung Morawa (skripsi). Medan: Universitas Sumatera Utara; 2010.

11. Sudoyo AW, Setyohadi B, Alwi I, Simadibrata M, Setiati S. Buku ajar ilmu penyakit dalam jilid II. Edisi ke-5. Jakarta.: Pusat Penerbitan IImu Penyakit Dalam FKUI; 2009:599-600.
12. Samara da Silva, de Farias Junior. Risk factors associated with high blood pressure in adolescents. Rev Bras Med Esporte. 2007;13(4).

13. Wendy, et al. Marital quality and marital bed: examining the covariation between relationship quality and sleep. Sleep Med Rev. 2007;11(5): 389-404.

14. Folkow B. Mental distress and its importance for cardiovascular disorder: physiological aspects, "from mice-to-man". Scand Cardiovascular Journal. 2001;35:163-72. 